present time when we are trying to understand the factors that determine the survival of species and thereby, perhaps, learning how to prevent our own disappearance from the planet.

After the Editor's introductory chapter, which sets the scene geologically as well as stressing the value of amateur natural history studies, there follows a masterly and up-to-date account of the vegetation of Britain, treated historically as well as ecologically, by Dr. Francis Rose. This is the largest section of the book, which continues with excellent essays on Invertebrates by Michael Chinery; the Seashore by Sir Maurice Yonge; Fishes, both freshwater and marine, by T. B. Bagenal; Amphibia and Reptiles by Alfred Leutscher; Birds by Kenneth Williamson; and Mammals by Richard Fitter.

This is natural history at its best, embellished by a wealth of illustrations in both colour and monochrome by a team of artists: Norman Barber, John Flower, Timothy Greenwood, David Nockels, Richard Orr and John Rignall.

As Dr. Burton points out, the spread of knowledge of our flora and fauna among a wider public increases hopes of limiting the encroachment on our open spaces and of staying the woodman's axe - or its modern equivalent. This well-written and beautifully illustrated book should do much to achieve this aim.

JOHN CLEGG

\title{
They All Ran Wild by Eric C. Rolls. Angus and Robertson, £3.25
}

It is unusual for a farmer, in any country, to spend most of four years away from his property, roaming a continent, talking to scientists, historians, landholders, operators, pest destruction boards, and reading all he can find about animals, mainly introduced, which have become pests. When the country is Australia and the farmer is also a poet, who writes engagingly about a life-long interest, the result is an unusual and very readable book.

Inevitably, half the book is about rabbits; the early and unsuccessful attempts to introduce them, their establishment as prized sporting animals in 1859 , and their subsequent spread over the country as 'the drab grey blanket' which brought ruin to so many graziers. The development of the trade in rabbit carcases and skins is well chronicled (the author spent many days in libraries conscientiously searching the files of nineteenth-century newspapers, parliamentary papers and other records), as is the legislation against rabbits and the attempted control, by traps, fumigation, poison baits and disease, culminating in the eventual introduction of myxomatosis.

The second half deals with the less well known introductions of hares (for coursing - banned in 1953), foxes, donkeys, camels, dogs, pigs, cattle, goats and horses - all of which established themselves in the wild. Heroic efforts were made to introduce alpacas from Peru but they all died within a few years of their arrival. There are, finally, chapters on dingoes, which cannot be tolerated in sheep country, and the highly indigenous kangaroos, which sometimes compete with domestic livestock but can also be managed, and conserved, as a highly efficient protein-producing crop.

This book is not only about the imported animals; it is about the country itself - its variety and charm, droughts, floods, fires and sometimes inimical character. Also, on a muted note, it is about the author, his own life on the land, his journeying and his reflections. There is a good bibliography, an index and relevant photographs.

HARRY V. THOMPSON 